\title{
Fat Kids Can't Do Maths: Negative Body Weight Stereotyping and Associations with Academic Competence and Participation in School Activities Among Primary School Children
}

\author{
Bronwyn Chalker and Jennifer A. O’Dea*
}

Faculty of Education \& Social Work, University of Sydney, NSW, 2006, Australia

\begin{abstract}
Aim: To investigate children's body image, perceptions of the academic abilities of thin and fat children and whether body image influences student's academic confidence and/or participation in school classroom activities.

Methods: The Children's Body Image Scale (CBIS) depicting seven figures ranging from thin (A) to fat (G) and individual one-on-one interviews were completed by 15 children aged 8 to 10 years.

Results: The thinnest CBIS figures (A, B) were the most nominated 'ideals'. Children with two largest figures, F or G were not nominated as ideal. Thin children were generally ranked as best and perceived as kind; happy; small eaters and socially successful. Fat children were perceived as unintelligent; lazy; greedy; unpopular; bullying and unable or unwilling to play physical games. Thin children were perceived as best at sport; dancing; mathematics and giving speeches. No fat children were perceived as best at any of the academic skills.

Conclusion: Body image ideals and fat stereotypes are well entrenched among children although it did not appear to adversely affect their academic confidence and participation in school activities at this age. Teachers and health educators could promote children's participation in academic activities and encourage well being by implementing programs that increase acceptance of a wide range of healthy, and active body shapes.
\end{abstract}

Keywords: Body image, weight, stereotyping, school children, academic perceptions.

\section{INTRODUCTION}

Research over the past few decades has established widespread body dissatisfaction in adolescents, especially females [1] and slim body ideals have been identified in preadolescent children [2,3]. Australian studies also report that slimness is an ideal prevalent in young boys and girls [4, 5].

Although it is possibly considered 'normal', at least in girls, body dissatisfaction in children is not benign because it correlates with poor psychological functioning [6], lower self-worth and high "drive for thinness" [7]. Poor body image also plays predictive roles in the development of dieting and disordered eating [8] and poorer general self perceptions [9].

Weight stereotypes and prejudice against overweight people is known to be prevalent among adults, including health professionals, who generally assign negative stereotypes and high levels of stigma to overweight people $[10,11]$. Overweight adolescents are more socially isolated than their normal weight peers, due to stigma [12]. In a longitudinal study of 11 to 13 year old girls, [9] heavier girls had lower self-worth and considered themselves much less accomplished socially, academically, athletically, romantically, and with regard to their attractiveness, friendships,

*Address correspondence to this author at the Faculty of Education \& Social Work, University of Sydney, Building A35, NSW, 2006, Australia; Tel: 612-93516226; Fax: 61-2-93512606; E-mail: j.o'dea@edfac.usyd.edu.au behavior and job competence. The results of this study showed that the girls considered themselves to be less intelligent and academically competent than their lower weight peers, based purely on their body weight perceptions.

These findings suggest that adolescent's poor self image is reflected in their poor body image and their desire to seek the "perfect" body, which is characterized by slimness in females and slim/muscularity in males. These "perfect" body ideals are largely unattainable by most individuals and the pursuit of them often translates into repeated failure, further weight gain and lower self worth. The current study seeks to investigate these phenomena in younger children to examine if body image issues affect primary school children's academic self concept as well as self image related to children's participation in classroom and physical education activities.

The major research question in the current study was "How do primary school children perceive their own bodies and those of others and do children's body image perceptions relate to their perceptions of and confidence in academic activities, sporting ability and other school activities?"

\section{METHODS}

\section{Study Design}

The study employed qualitative methods including stimulus questions related to the children's body image questionnaire followed by one-on-one interviews with each child. 
Participants were 6 boys and 9 girls aged 8-10 years at a public primary school in Sydney, Australia who were recruited using a convenience sample. This preadolescent age group was selected to avoid the confounding effect of puberty on body image [13].

\section{Instruments}

A validated Australian body image scale, the Children's Body Image Scale (CBIS) [14] was completed by each student at the beginning of the interview to assess their body image and used as a stimulus for interview questions. The seven male and female figures in the CBIS (Fig. 1) range in size from basic categories of "thin (A) to fat (G)" and are matched to the seven conventional U.S. National Center for Health Statistics Body Mass Index percentile ranges [15]. The facial features of the figures were removed in order to allow for interpretation from child of different ethnic backgrounds.
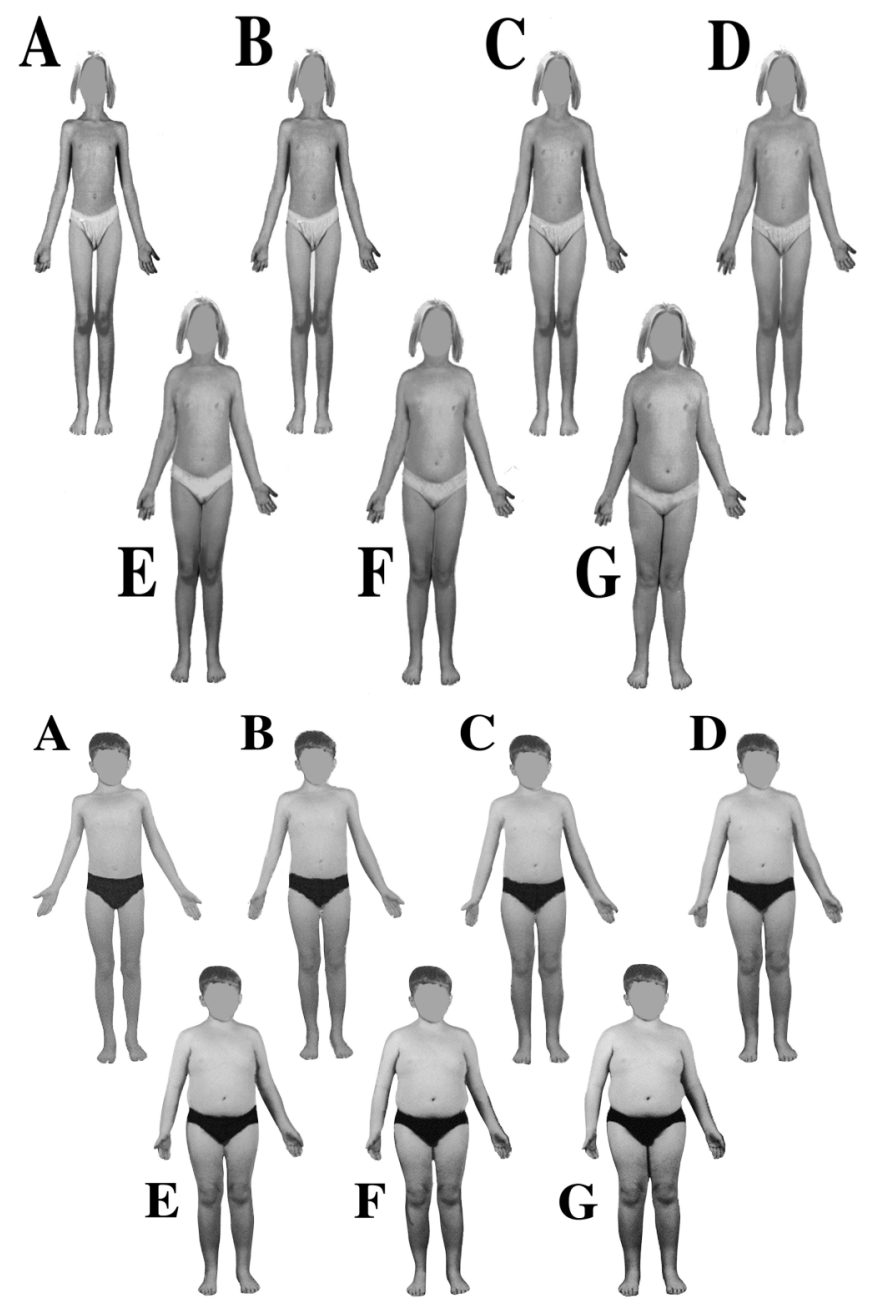

Fig. (1). Range of female and male figures in the Children's Body Image Scale [14].

One-on-one interviews explored the children's perceptions of academic achievement, sporting ability and social acceptance among children of different body sizes. Children's confidence, participation and performance in school activities were assessed by asking whether: they had ever participated in a school performance; they liked making speeches at school; they liked school PE and school sport; they liked helping their teacher at the front of the classroom and how they perceived their performance at school work (Table 1).

Table 1. Summary of One-on-One Interview Questions

- Researcher points in turn to thinnest, middle and fattest figures A, D and G and each time asks, "What do you think this person is like?"

- "Do you think he/she is: happy or sad? Why? good at school work? Why? shy or confident? Why? nice? Why? has lots of friends? Why?"

- "Do you think you would like to be friends with him/her? Why / Why not?"

- Researcher points to all Figures $A$ to $G$ and asks:

- "Who do you think would be the best at: sport? Why?" dancing? Why?" maths? Why?" acting in a play? Why?" giving speeches? Why?" playing video games? Why?"

- "Which one do you think you would like the best? Why?"

- "Which one do you think looks the best? Why?"

- "Do you like doing sport or PE/speeches/helping at the front of the room? Why?"

- "Do you think you're good at school work?"

- "Have you been in a school concert, or a play or a performance?" Why/Why not?

\section{Procedure}

Approval was obtained from the University Human Research Ethics Committee and the Department of Education and Training. Written parental consent was obtained for each student. Interviews with each child were conducted in private by the first author and recorded using a tape recorder. Recordings were then transcribed verbatim by the first author and analyzed using a thematic content analysis wherein children's comments were coded according to major and minor themes that arose.

\section{Coding and Analyses}

The transcriptions of each interview were then analyzed by both authors independently to develop a detailed coding scheme and subset of themes. The coding forms are available from the second author upon request. The data were then analyzed using a content analysis [16, 17] which involved the systematic examination of the transcripts to identify and group emergent clusters and themes and then code, classify and develop major categories of themes. Subsets of transcripts were read independently by the authors to provide feedback on the coding scheme that would facilitate the generation of themes. Open, axial and selective coding was used to code, sub-categorize and unify coding of the transcript text. The analytical methods basically employed inductive thematic analysis [16, 17] and grounded theory $[16,17]$ to develop and interpret the themes.

\section{RESULTS}

The general, descriptive results of CBIS- based interviews revealed that only 2 of the 9 girls were satisfied with their current body size; 5 wanted to be thinner and 2 wanted to be bigger.

Of the six boys in the study, none wanted to be bigger; 1 of 5 wanted to be smaller and 4 of 5 wanted to be their current size. 
Table 2. Children's Perceptions of Thin Children (Figures A and B)

\begin{tabular}{|c|c|c|}
\hline Theme & "What is this Person Like? & $\begin{array}{c}\text { Reasons Given for Participant Perceptions and Typical Comments } \\
\text { from Children }\end{array}$ \\
\hline \multirow{11}{*}{ Thin children are kind } & Nice & "some people who's skinny and stuff... they're really kind to me" \\
\hline & Lots of friends & "because she's nice" \\
\hline & What she/he might be like... & "Tall and skinny, kind and doesn't eat very much" \\
\hline & & "kind guy, shares things" \\
\hline & Would like to be friends with & "she's kind, and she'll help me with my work." \\
\hline & & "she's happy and she's nice... she's not a mean person" \\
\hline & & "she might be pretty, and nice" \\
\hline & & "he looks like he's kind" \\
\hline & Liked best & "Looks like a good guy" \\
\hline & & "He looks friendly" \\
\hline & Friends would like best & $\begin{array}{l}\text { He would be "kind to them" } \\
\text { "He might be nice... and give them lollies... and won't have no fights, } \\
\text { they'll just play" }\end{array}$ \\
\hline \multirow{7}{*}{ Thin children are happy } & Happy & "he's the skinniest one... and he likes to be that" \\
\hline & & "he’s skinny" \\
\hline & & "he's not real big" \\
\hline & Nice & "would be kind because he's happy" \\
\hline & & "because she’s happy" \\
\hline & & "she's skinny and she's happy" \\
\hline & Confident & "because he's happy" \\
\hline \multirow{4}{*}{$\begin{array}{l}\text { Thin } \\
\text { children do not eat much }\end{array}$} & What she/he might be like... & "tall and skinny, kind and doesn't eat very much" \\
\hline & Liked best & "she's medium, and she doesn't eat really that much" \\
\hline & Sad & "she needs to eat more" \\
\hline & $B$ is best at sport & $\begin{array}{l}\text { "Maybe A... she might not have energy because she doesn't really eat a } \\
\text { lot" }\end{array}$ \\
\hline \multirow{3}{*}{$\begin{array}{l}\text { Thin children are socially } \\
\text { successful }\end{array}$} & Has a lot of friends & "lots of skinny boys in our school make lots of friends" \\
\hline & & "all of these (other figures in CBIS) are her friends" \\
\hline & $\begin{array}{l}\text { Friends would } \\
\text { like best }\end{array}$ & "Because she's kind of skinny" \\
\hline \multirow{3}{*}{$\begin{array}{l}\text { Thin children are likely to be } \\
\text { teased because they are small }\end{array}$} & Shy & “"cos she can't fight... she doesn't stick up for herself" \\
\hline & Sad & "people tease them because she's so skinny" \\
\hline & Does not have many friends & $\begin{array}{l}\text { "'cos he doesn't talk to little kids like him" } \\
\text { "she's shy, she won't have the guts to talk to anyone" }\end{array}$ \\
\hline
\end{tabular}

The three thinnest Figs. (A and B) were perceived by both males and females as the most nominated 'ideals'. Children with two largest figures, $F$ or $G$ were not nominated as their ideal. No variation occurred according to the gender of the body figure pictures.
Table 2 presents the students' perceptions of pictures of the thinnest Figs. (A and B). Thin children were perceived as kind; happy; small eaters; socially successful and likely to be bullied because they are small (Table 2). There were no apparent differences between the participants' perceptions of 
Table 3. Children's Perceptions of Fat Children (Figs. G and H)

\begin{tabular}{|c|c|c|}
\hline Theme & "What is this Person Like? & Reasons Given for Participant Perceptions and Typical Comments from Children \\
\hline \multirow{6}{*}{$\begin{array}{l}\text { Fat children are not } \\
\text { intelligent } \\
\text { Fat children are lazy } \\
\text { overeaters }\end{array}$} & Not good at school work & "instead of thinking she probably eats a lot" \\
\hline & Best at video games & "he doesn't look fit... He plays video games all day... he doesn't exercise" \\
\hline & & "she like, eats, and, like, she'll play video games as well." \\
\hline & & "maybe he's lazy, he won't get up, he just sits and plays" \\
\hline & & "She's lazy... she eats while she's playing games" \\
\hline & & $\begin{array}{l}\text { "People who are lazy and stuff, they like to play video games and not do anything else } \\
\text { except eat, play, eat, play and watch movies." }\end{array}$ \\
\hline \multirow{13}{*}{$\begin{array}{l}\text { Fat children are not } \\
\text { popular }\end{array}$} & Does not have many friends & "Cos some people don't like fat people" \\
\hline & & “Cos people tease him" \\
\hline & & "maybe some people would hate her because of the way she looks" \\
\hline & & "because people tease her" \\
\hline & Sad & "people might tease him about what he looks like... 'cos he's big" \\
\hline & & "maybe people tease her because she's fat" \\
\hline & & "everybody tease her, 'cos she's fat" \\
\hline & & "maybe he doesn't got friends" \\
\hline & Would not like to be friends & "Cos he doesn't have lots of friends" \\
\hline & Best at video games & $\begin{array}{l}\text { "he might be a nerd... Some big guys like him... stay home and play... "cos he might have } \\
\text { no friends... he might be a loner" }\end{array}$ \\
\hline & Would like to be friends with & "she’s lonely" \\
\hline & & “"cos probably he doesn't have any friends" \\
\hline & & $\begin{array}{l}\text { "Maybe she didn't have any friends, and I feeled slack and I told her, 'If you wanna play } \\
\text { with us..." }\end{array}$ \\
\hline \multirow{5}{*}{$\begin{array}{l}\text { Fat children are } \\
\text { unable or unwilling } \\
\text { to play }\end{array}$} & What she/he might be like... & "a not good player... of soccer" \\
\hline & Might not like & "Maybe he won't listen... when you play" \\
\hline & & $\begin{array}{l}\text { "I don't like friends that are lazy and don't do anything... if you play something they } \\
\text { always have to say 'I'm out, I wanna play something else.". }\end{array}$ \\
\hline & Shy & "she doesn't want to tell anybody to play with her... she doesn't really like playing" \\
\hline & Sad & $\begin{array}{l}\text { "Because she doesn't feel like she's with the group anymore... she wanted to play but they } \\
\text { were all playing with something different she couldn't play with" }\end{array}$ \\
\hline \multirow{16}{*}{$\begin{array}{l}\text { Fat children are } \\
\text { mean and are bullies }\end{array}$} & Not nice & "doesn’t look like a nice person... looks like a bully" \\
\hline & & "because he's angry" \\
\hline & Sad & "he's got no friends... 'cos when people want something he doesn't give it to them" \\
\hline & & "because no-one likes him... because he's angry" \\
\hline & What she/he might be like... & "would be angry... because he kind of looks, like, big" \\
\hline & & $\begin{array}{l}\text { "really meaner than D... Because she's fat and sometimes people are mean, when people } \\
\text { are teasing her" }\end{array}$ \\
\hline & & "Angry because... he's big" \\
\hline & & was "Angry ... she bullies people... because she's fat" \\
\hline & & "Mean... he's big... some big people are mean" \\
\hline & & "looks like a toughie because of her arms" \\
\hline & Does not have many friends & "Cos he teases everyone" \\
\hline & & "she's kind of mean to other people" \\
\hline & & "he doesn't be nice to his friends, he only be's nice to... little kids" \\
\hline & Would not like to be friends with & "They look like big tough girls... eat our food" \\
\hline & & "she'll probably be mean" \\
\hline & Might not like & "Cos they look not friendly" \\
\hline
\end{tabular}


Table 4. Children's Perceptions of Skills Among Children of Thin, Fat and Mid-Range Body Size

\begin{tabular}{|c|c|c|}
\hline Theme & Question & Reasons Given \\
\hline $\begin{array}{l}\text { Thinner children are } \\
\text { faster and fitter }\end{array}$ & Who would be the best at sport? & $\begin{array}{l}\text { "he's probably fast" } \\
\text { "he's skinny and he's fit" } \\
\text { "she can run fast... because she's a bit skinnier" } \\
\text { "she's good and fit" } \\
\text { "He looks healthy" } \\
\text { "she is light and she can run a lot, not like the other one that is, um, not that skinny, they } \\
\text { might be a bit slow" } \\
\text { "she's a bit skinny, and skinny people can run fast... and, she's tall." } \\
\text { "He's a bit big, and a bit fast, but A's faster, but... he can shoulder-barge people off" }\end{array}$ \\
\hline & Who would be the best at dancing? & $\begin{array}{l}\text { "he's skinny... he can move fast" } \\
\text { "he looks fit" } \\
\text { "a bit skinny so he can dance and he's flexible" } \\
\text { "she's not too fat and she's not too skinny, she's normal..." } \\
\text { "she has a good body for dancing" }\end{array}$ \\
\hline $\begin{array}{l}\text { Mid-range children } \\
\text { (C, D, E) are most } \\
\text { confident and skilled } \\
\text { at performance }\end{array}$ & $\begin{array}{l}\text { Who would be best at giving } \\
\text { speeches? }\end{array}$ & $\begin{array}{l}\text { "She's not that shy or anything... she will say it" } \\
\text { "He won't be shy... might be a real good talker" } \\
\text { "She can talk loud" } \\
\text { "She looks a bit confident" } \\
\text { "Because she looks confident" }\end{array}$ \\
\hline & $\begin{array}{l}\text { Who would be best at acting in a } \\
\text { play?' }\end{array}$ & $\begin{array}{l}\text { "He might be real confident... Might talk real good" } \\
\text { "if they made her... a princess, she can, like, fit into dresses, and she might have a cool } \\
\text { voice" }\end{array}$ \\
\hline $\begin{array}{l}\text { 'Fat' children (F \& } \\
\text { G) are comical or } \\
\text { menacing }\end{array}$ & $\begin{array}{l}\text { Who would be best at acting in a } \\
\text { play?' }\end{array}$ & $\begin{array}{l}\text { "she could boss around people and make us laugh" } \\
\text { "acting as a Big Mamma..." } \\
\text { "she can be the Big Bad Wolf" }\end{array}$ \\
\hline
\end{tabular}

Fig. (A) as male or female. Fat children (F and $\mathbf{G})$ were perceived as unintelligent; lazy; greedy with food; not popular with other children; unable or unwilling to play physical games and likely to be a bully (Table 3 ). There were no apparent differences between the participants' perceptions of Figs. ( $\mathbf{F}$ and $\mathbf{G}$ ) as male or female.

Of the children who answered each of the questions, the thinnest Figs. (A and B) were perceived as the best at sport $(13 / 15)$; dancing (11/15); mathematics (10/15) and giving speeches (7/15). The fattest Fig. (G) was not selected as the best at any of these skills. The fattest Figs. ( $\mathbf{F}$ and $\mathbf{G})$ were selected as being the best at acting, particularly in humorous roles (8/12) and playing video games (11/13). Participants' explanations for these skill ratings are given in Table 4.

Participants reported that Figs. (A and B) looked best $(10 / 12)$ and that they liked Figs. (A and B) the best (8/15). Fig. (G) was liked least $(10 / 15)$. The thinnest figures were most frequently 'liked best' by male and female participants.
Explanations of their preference for these choices included "She's not too fat, she's not too skinny, she's a normal girl"; "For A, he/she really doesn't eat a lot, B just eats a bit, G doesn't exercise, $\mathrm{F}$ he/she doesn't exercise and doesn't really do a lot of things, and I think G's lazy".

The students' actual body size did not influence participation as reported by students, with the majority reporting enjoying performances $(10 / 15)$; speeches $(11 / 15)$; school sports (15/15); helping at the front of the classroom $(12 / 15)$ and perceived themselves to be good at schoolwork $(11 / 15)$. Those who gave reasons considered it 'fun'. Four children did not enjoy giving speeches or performing at school but these children were of mid-range body size $(\mathbf{C}, \mathbf{D}$, E), as identified by the researchers and they did not refer to any indication of weight or body image issues. Six children reported having avoided school speeches or performances because of their inhibitions. Reasons given invariably concerned nervousness and shyness, but none reported weight or shape concerns as a reason not to be involved in these activities. 


\section{DISCUSSION}

Our findings suggest that body image stereotypes and weight prejudice appear to be well-entrenched among primary school students with several students reporting their peers to be less intelligent, less academically competent and less able to participate in athletic pursuits if they were of a bigger, fatter body size than average.

The primary school students who participated in our study viewed thin children far more positively than fat children and weight prejudice was prevalent amongst this sample of children as in previous studies of older adolescents and adults [4, 10-12]. Whilst the finding that weight prejudice and the belief that "largeness" or fatness equates with less intelligence and control over one's eating and one's life in general has been found among health professionals $[18,19]$, the young age group of the students presenting such prejudice in this study is concerning because it may impact on the self image of their peers. Whilst the study was limited in size and coverage of the sample, this exploratory work can be seen as constituting a good basis for larger-scale studies with the trends among the findings suggest that the views of primary school aged children strongly reflect stereotypes regarding a person's weight and their abilities in regard to academic competence, athletic performance and general competencies.

A major research question of the current study was "Could children's body image concerns affect their confidence and participation in school activities?" and our results suggest that the child's body size did not impact upon their own self perceptions, but were certainly prejudices that they held against other larger than average sized children. This may reflect an explanation for the general lower sense of self esteem and poor body image that has been observed and reported among studies of large adolescents [9-12].

The finding that weight prejudice and body image stereotyping occurs among primary aged children may not currently adversely impact upon their participation and confidence in school activities, but it could impact on their peers because it is likely to result in stigma, be self perpetuating, resulting in even lower participation, underachievement and a vicious cycle of poor participation and performance. Poor body image resulting in low participation in sport and PE is known to occur in adolescents [20] and it is also likely to result in less exercise, further weight gain and social isolation [21].

In relation to the significance of our findings, we suggest the implementation of enjoyable non-competitive physical activities in primary school settings to improve participation and confidence for children with a poor body image [20,22] and in turn, a more positive body image is likely to be achieved. Teachers, school principals, health professionals and parents can help to change this situation by adopting anti-bullying programs that include an emphasis on the unacceptability of any weight-related teasing; making certain to include the bigger children in a wide array of school activities and by taking care not to encourage or perpetuate these negative stereotypes when discussing the topics of food, nutrition, health or physical activity with children.

This small explorative study has limitations including a small sample size from only one particular Australian public primary school. Despite this design weakness, the current research study provides rich data and a large amount of indepth interview time on the topic of weight perceptions among primary school children. This study has produced a valuable qualitative picture of children's weight perceptions and prejudices.

Teachers, educators, health professionals and producers of mass media, should take a very careful approach to the issue of child health promotion, especially in relation to body weight, shape and childhood obesity, if we are to avoid doing more harm than good [23]. School interventions that focus on self-esteem and media literacy have proven successful in improving students' body image [24] but programs that focus on weight issues and/or weight loss are likely to do more harm than good to the psychosocial health of young people. Teachers, parents and health education professionals could greatly contribute to child well-being by developing programs designed to increase the acceptance of a wide range of healthy, active body shapes.

\section{REFERENCES}

[1] Jones DC, Vigfusdottir TH, Lee Y. Body image and the appearance culture among adolescent girls and boys: an examination of peer criticism, appearance magazines, and the internalisation of appearance ideals. J Adolesc Res 2004; 19 (3): 323-39.

[2] McCabe M, Ricciardelli L. Parent, peer and media influences on body image and strategies to both increase and decrease body size among adolescent boys and girls. Adolescence 2001; 36(142): 22540 .

[3] Cohane GH, Pope HGJ. Body image in boys: a review of the literature. Int J Eat Disord 2001; 29(4): 373-79.

[4] Tiggemann M, Wilson-Barrett E. Children's figure ratings: relationship to self-esteem and negative stereotyping. Int $\mathrm{J}$ Eat Disord 1999; 23: 83-88.

[5] Birbeck D, Drummond M. Interviewing, and listening to the voices of, very young children on body image and perceptions of self. Early Child Dev 2005; 176(6):579-96.

[6] Phares V, Steinberg AR, Thompson JK. Gender differences in peer and parental influences: body image disturbance, self-worth, and psychological functioning in preadolescent children. J Youth Adolesc 2004; 33(5):421-29.

[7] Sands R, Tricker J, Sherman C, Armatas C, Maschette W. Disordered eating patterns, body image, self-esteem, and physical activity in preadolescent school children. Int J Eat Disord 1997; 21(2): 159-66.

[8] Mellin A, Neumark-Sztainer D, Story M, Ireland M, Resnick M. Unhealthy behaviours and psychosocial difficulties among overweight adolescents: The potential impact of familial factors. J Adolesc Health 2002; 31(2):145-53.

[9] O'Dea JA. Self-concept, self-esteem and body weight in adolescent females: a three-year longitudinal study. J Health Psychol 2006; 11(4): 599-611.

[10] Latner J, Stunkard A. Getting worse: the stigmatization of obese children. Obes Res 2003; 11(3): 452-6.

[11] Latner J, Stunkard A, Wilson GT. Stigmatized students: age, sex and ethnicity effects in the stigmatization of obesity. Obes Res 2005; 13(7):1226-31.

[12] Strauss R, Pollack H. Social marginalization of overweight children. Arch Pediatr Adolesc Med 2003; 157: 746-52.

[13] Abraham S, O'Dea J. Body mass index, menarche and perception of dieting among peripubertal adolescent females. Int $\mathrm{J}$ Eat Disord 2001; 29(1): 23-28.

[14] Truby H, Paxton SJ. Development of the Children's Body Image Scale. Br J Clin Psychol 2002; 41:185-203.

[15] Hammill PVV, Drizd TA, Johnson CL, Reed RB, Roche AF, Moore WM. Physical growth: National Center for Health Statistics percentiles. Am J Clin Nutr 1979; 32: 607-29.

[16] Miles MB, Huberman AM. Qualitative data analysis: an expanded sourcebook. California: Thousand Oaks, Sage 1994. 
[17] Pope C, Mays N. Reaching the parts other methods cannot reach: An introduction to qualitative methods in health and health service research. Br Med J 1995; 311: 42-5.

[18] Schwartz, O’Neal CH, Brownell K, Blair S, Billington C. Weight bias among health professionals specializing in obesity. Obesity Res 2003;11:1033-9.

[19] Teachman BA, Brownell K. Implicit anti-fat bias among health professionals: Is anyone immune? Int J Obes Relat Metab Disord 2001; 25:1525-31

[20] Telford RD. Low physical activity and obesity: causes of chronic diseases or simply predictors? Med Sci Sports Exer 2007; 39:123340
[21] Faith MS, Leone MA, Ayers TS, Heo M, Pietrobelli A. Weight criticicsm during physical activity, coping skills, and reported physical activity among children. Pediatrics 2002; 110(2): 22-3.

[22] Leslie J, Yancy A, McCarthy W, et al. Development and implementation of a school-based nutrition and fitness promotion program for ethnically diverse middle-school girls. J Am Diet Assoc 1999; 99(8):967-70.

[23] O'Dea JA. Prevention of child obesity: first, do no harm. Health Educ Res 2004; 20(2): 259-65.

[24] McVey GL, Davis R, Tweed S, Shaw B F. Evaluation of a schoolbased program designed to improve body image satisfaction, global self-esteem, and eating attitudes and behaviors: a replication study. Int J Eat Disord 2004; 36: 1-11.

(C) Chalker and O'Dea; Licensee Bentham Open.

This is an open access article licensed under the terms of the Creative Commons Attribution Non-Commercial License (http://creativecommons.org/licenses/by$\mathrm{nc} / 3.0 /$ ) which permits unrestricted, non-commercial use, distribution and reproduction in any medium, provided the work is properly cited. 